\section{Comparison of Kasugamycin to Traditional Bactericides for the Management of Bacterial Spot on Tomato}

\author{
Gary E. Vallad ${ }^{2}$ \\ University of Florida, Gulf Coast Research and Education Center, 14625 CR \\ 672, Wimauma, FL 33598
}

Kenneth L. Pernezny

University of Florida, Everglades Research and Education Center, 3200 E. Palm Beach Road, Belle Glade, FL 33430

\author{
Botond Balogh \\ University of Florida, Plant Pathology Department, Gainesville, FL 32611
}

Aimin Wen

North Dakota State University, Department of Plant Pathology, Fargo, ND 58108

Jose Francisco L. Figueiredo, Jeffrey B. Jones, and Timur Momol University of Florida, Plant Pathology Department, Gainesville, FL 32611

Rosa M. Muchovej ${ }^{1}$

US Sugar Corporation, 111 Ponce de Leon Avenue, Clewiston, FL 33440

Nikol Havranek and Nadia Abdallah

University of Florida, Everglades Research and Education Center, 3200 E. Palm Beach Road, Belle Glade, FL 33430

\section{Steve Olson}

University of Florida, North Florida Research and Education Center, Quincy, FL 32351

\section{Pamela D. Roberts}

University of Florida, Southwest Florida Research and Education Center, Immokalee, FL 34142

Additional index words. kasugamycin, tomato, Solanum lycopersicon, Xanthomonas perforans, bacterial spot, bactericides, fungicides

\begin{abstract}
Studies were conducted at three locations in Florida to evaluate the effects of kasugamycin alone, in alternation, or as a tank-mix partner with copper bactericides and other fungicides against bacterial spot of tomato. In greenhouse trials, kasugamycin, formulated as Kasumin ${ }^{\circledR} 2 \mathrm{~L}$, reduced bacterial spot severity by up to $37.5 \%$ compared with a non-treated control. Little advantage in disease control was observed by mixing kasugamycin with other fungicides. Kasugamycin was assessed in six field trials. In the four field trials that tested kasugamycin alone, it was as effective as the standard copper + mancozeb treatment for the control of bacterial spot. In four trials, no benefit was observed in applying kasugamycin as a mixture with copper + mancozeb, and only one of three trials did alternating kasugamycin with copper + mancozeb improve bacterial spot control over either the copper + mancozeb standard or kasugamycin alone. Although kasugamycin was effective for the control of bacterial spot in greenhouse and field trials, rapid development of resistance in field populations of $X$. perforans may shorten the effective use of this antibiotic.
\end{abstract}

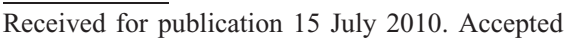
for publication 29 Sept. 2010.

This research was supported in part by a grant from USDA, SARE (Momol, Jones, Ji, Olson, 2006-2009). ${ }^{1}$ Chief Soils Scientist.

${ }^{2}$ To whom reprint requests should be addressed; e-mailgvallad@ufl.edu.

Bacterial spot is a major disease of tomato (Solanum lycopersicum) in Florida and worldwide (Jones, 1991; Jones et al., 2004). The disease is associated with four species of Xanthomonas: $X$. euvesicatoria, $X$. vesicatoria, $X$. perforans, and $X$. gardneri that until recently were classified as $X$. axonopodis pv. vesicatoria (also referred to as $X$. campestris pv. vesicatoria) and $X$. vesicatoria (Jones et al., 2004; Vauterin et al., 1995). X. perforans predominates in tomato fields in Florida. The bacterium infects all aerial portions of the plant causing circular, necrotic lesions typically less than $3 \mathrm{~mm}$ in diameter on stems, leaves, and fruits (Jones, 1991). Infected fruit exhibit large, scabby, raised lesions that render fruit nonmarketable. Estimated yield losses of up to $50 \%$ have been associated with bacterial spot (Pohronezny and Volin, 1983; Scott et al., 1989). Nationwide, Florida is the largest producer of fresh-market tomatoes accounting for $31 \%$ of 44,600 ha planted annually in the United States and for $40 \%$ of the $\$ 1.3$ billion value (USDA, 2010). VanSickle and Weldon (2009) used a representative farm model to estimate monetary losses in southwest Florida resulting from bacterial spot at $\$ 3090$ per acre based on 2007-2008 production costs and market values.

Integrated management strategies for bacterial spot include using certified seed, diseasefree transplants, field rotation, avoidance of cull piles, and the application of bactericides that are usually copper-based (Jones 1991; Jones and Jones, 1985). Although host resistance has been identified in tomato (Scott and Jones, 1986; Scott et al., 1997), commercial cultivars lack resistance to the predominant Florida field races of $X$. perforans (race 3 and 4). These breeding efforts have been hindered as a result of frequent changes in the pathogen population (Jones et al., 1998). Grower reliance on copper-based bactericides and intense production practices (i.e., consolidation of acreage, decreased rotation periods, increased movement of plant materials) has led to the spread and establishment of copperresistant Xanthomonas strains in many production areas. A 2006 survey of 377 bacterial spot-causing strains in Florida not only confirmed the predominance of $X$. perforans races 3 and 4 , but that all strains were tolerant to copper (J.B. Jones, unpublished data). To suppress copper-tolerant strains, growers tank-mix copper bactericides with an ethylenebisdithiocarbamate (EBDC) such as maneb or mancozeb, which improves copper solubility and bacterial spot control (Marco and Stall, 1983; Ritchie and Dittapongpitch, 1991). Despite frequent sprays, copper compounds with EBDCs still have limited efficacy, may cause phytotoxicity, and both chemicals may face increased regulation as a result of environmental and health concerns.

Additional means to suppress bacterial diseases use systemic acquired resistance (SAR) inducers, biological control agents, novel compounds, and antibiotics (streptomycin and oxytetracycline) (Byrne et al., 2005; Flaherty et al., 2000; Louws et al., 2001; Obradovic et al., 2004, Roberts et al., 2008). Acibenzolar$S$-methyl (ASM) (Actigard ${ }^{\circledR} 50 \mathrm{WG}$; Syngenta Crop Protection, Greensboro, NC), an SAR inducer, reduces bacterial spot symptoms; however, the disease reduction level is usually only as good as copper and mancozeb sprays (Roberts et al., 2008). Furthermore, fullseason use of ASM alone is not recommended as a result of the potential for adverse 
effects on plant growth and yield (Graves and Alexander, 2002; Louws et al., 2001; Romero et al., 2001). Biological control agents typically have limited efficacy in the field, but recent research efforts have focused on their incorporation into integrated disease management programs (Fravel, 2005). Bacteriophages have recently shown to be effective alternatives to the standard copper bactericides, reducing disease severity of bacterial spot and enhancing yields in field trials (Balogh et al., 2003; Flaherty et al., 2000; Obradovic et al., 2004). Famoxadone plus cymoxanil (Tanos ${ }^{\circledR}$; E.I. du Pont de Nemours and Company, Wilmington, $\mathrm{DE}$ ) and other materials were also useful in suppression of bacterial spot on tomato (Roberts et al., 2008). The use of antibiotics, particularly streptomycin, resulted in development of widespread resistant populations (Minsavage et al., 1990; Ritchie and Dittapongpitch, 1991; Stall and Thayer, 1962). Programs using multiple products with diverse modes of action have shown promise for the management of bacterial diseases (Gent and Schwartz, 2005; Ji et al., 2006; Obradovic et al., 2004).

Kasugamycin \{3-O-[2-amino-4-[(carboxyiminomethyl) amino]-2,3,4,6-tetradeoxy$\alpha$-D-arabino-hexopyranosyl]-D-chiro-inositol\}, formulated usually as Kasumin ${ }^{\circledR} 2 \mathrm{~L}(2.3 \%$ a.i kasugamycin; Arysta LifeScience North America, LLC, Cary, NC), is an antibiotic only used in agriculture; there are no known medical or veterinary uses. Kasugamycin is labeled for several bacterial diseases on a number of crops and is used to control bacterial spot on tomatoes and pepper in Mexico. In the United States, registration for the antibiotic is pending; however, tolerances were established for residues on imported tomatoes and peppers from Mexico (EPA, 2005). Because kasugamycin is an antibiotic, development of resistance in pathogen populations is a concern. A recurrent problem with antibiotic use on crop plants in the past has been the development of resistance among bacterial pathogen strains. Many reports exist, in particular, of the development of resistance to streptomycin in Xanthomonas spp. (Pohronezny et al., 1992; Ritchie and Dittapongpitch, 1991; Stall and Thayer, 1962). This is of special concern, because kasugamycin and streptomycin have similar bacterial modes of action as inhibitors of protein synthesis (Woodcock et al., 1991). The effectiveness of available control strategies for bacterial spot on tomato is limited and generally not sufficient when environmental conditions are conducive to disease. A full label for kasugamycin use on tomato, if efficacious and durable, could prove beneficial to U.S. tomato growers for the control of bacterial spot.

Field and greenhouse experiments were conducted to determine the efficacy of kasugamycin with and without a copper bactericide for the control of bacterial spot. Traditional bactericides, in particular copper-based compounds, were compared with kasugamycin for bacterial spot control in the field. Strains were periodically collected during field trials to test for the development of resistance to kasugamycin to assess the timeline for any appearance of resistance. We also investigated the possi- bility of mixing copper bactericides with kasugamycin to mitigate some of the potential antibiotic resistance problems.

\section{Materials and Methods}

Bacterial strain preparation. Several strains of $X$. euvesicatoria and $X$. perforans were used in the experiments. Experiments performed at the Everglades Research and Education Center (EREC), Belle Glade, FL, used X. perforans strain T193 (Race 3); those at Southwest Florida Research and Education Center (SWFREC) used $X$. euvesicatoria strain T1 (Race 1) and X. perforans strain T3 (Race 3 ); and those at the Gulf Coast Research and Education Center (GCREC) and Plant Science Research and Education Unit (PSREU) used $X$. perforans strain T4 (Race 4). All strains were isolated from Florida tomato fields and were characterized as sensitive to the formulated product Kasumin ${ }^{\circledR}$ 2L. Inoculum from each strain was prepared by growing cultures for $3 \mathrm{~d}$ at $28{ }^{\circ} \mathrm{C}$ on glucose-nutrient agar, flooding plates with either sterile phosphate-buffered saline (Leben et al., 1968) or $10 \mathrm{~mm} \mathrm{MgSO}_{4}$ and adjusting resultant suspensions to $\approx 10^{6}$ colony-forming units (cfu)/mL for inoculations conducted at EREC and GCREC and to $10^{8} \mathrm{cfu} /$ $\mathrm{mL}$ for inoculations at SWFREC and PSREU. In all cases, either the surfactant Tween 80 (2 drops per $660 \mathrm{~mL}$ at EREC) or Silwett L77 $(0.025 \% \mathrm{v} / \mathrm{v}$ at GCREC and SWFREC) was added to the inoculum to enhance infection of leaf surfaces.

Test materials used in greenhouse and field trials were as follows: kasugamycin (Kasumin ${ }^{\circledR}$ 2L, 2.3\% kasugamycin hydroxide; Arysta LifeScience North America, LLC); copper hydroxide (either Kocide $^{\circledR}$ 2000, 53.8\%, metallic copper equivalent $35 \%$, or Kocide $^{\circledR} 3000$; $46.1 \% ; 30 \%$, metallic copper equivalent $35 \%$; E.I. du Pont de Nemours and Company); basic copper sulfate $(40 \%$ metallic copper equivalent, Cuprofix ${ }^{\circledR}$ Ultra 40D Disperss ${ }^{\circledR}$; United Phosphorous, Inc., King of Prussia, PA); captan (Captan ${ }^{\circledR}$ 50WP, 48.9\%, N-trichloromethylthio4-cyclohexene-1,2-dicarboximide; Arysta LifeScience North America, LLC); Kasuran ${ }^{\circledR}$ 50WP (5\% kasugamycin hydroxide and 45\% copper oxychloride; Arysta LifeScience North America, LLC); Transfix ${ }^{\circledR}$ (spreader sticker pinene polymer, alkylphenol ethoxylate; Agriliance, LLC, St. Paul, MN); and mancozeb products such as Manzate ${ }^{\circledR}$ 75DF or Manzate ${ }^{\circledR}$ Pro-Stick ${ }^{\mathrm{TM}}$ (75\% mancozeb; E.I. du Pont de Nemours and Company) or Penncozeb ${ }^{\circledR}$ 75DF (75\% man-

Table 1. Bacterial spot (Xanthomonas perforans) of tomato as affected by kasugamycin alone or combined with fungicides in the greenhouse at the Everglades Research and Education Center, 2006-2007.

\begin{tabular}{|c|c|c|}
\hline \multirow[b]{2}{*}{ Treatment (rate a.i./L) } & \multicolumn{2}{|c|}{ Disease severity $^{z}$} \\
\hline & Expt. 1 & Expt. 2 \\
\hline Untreated (control) & $35.2 \mathrm{a}^{\mathrm{y}}$ & $36.8 \mathrm{a}$ \\
\hline Kasuran ${ }^{\circledR} 50 \mathrm{WP}(2.5 \mathrm{~g})$ & $35.2 \mathrm{a}$ & $36.2 \mathrm{a}$ \\
\hline Kasugamycin $(5 \mathrm{~mL})$ & $27.4 \mathrm{~b}$ & $23.0 \mathrm{ab}$ \\
\hline Kasugamycin $(5 \mathrm{~mL})+\operatorname{captan}(9.0 \mathrm{~g})$ & $23.8 \mathrm{~b}$ & $29.3 \mathrm{~b}$ \\
\hline Kasugamycin $(5 \mathrm{~mL})+$ copper hydroxide $(5.8 \mathrm{~g})$ & $27.6 \mathrm{~b}$ & $28.6 \mathrm{~b}$ \\
\hline
\end{tabular}

${ }^{\mathrm{z} E s t i m a t e}$ of percentage of plant tissue exhibiting symptoms of bacterial spot.

${ }^{y}$ Means followed by the same letter are not statistically different according to Waller-Duncan's $k$-ratio $t$ test at $P \leq 0.05$.

cozeb; United Phosphorus, Inc.). Application regimes and rates for greenhouse and field trials are indicated in Tables 1 through 5.

Greenhouse experiments. Experiments were conducted in an air-conditioned greenhouse at EREC, Belle Glade, FL, between Dec. 2006 and Mar. 2007. Maximum temperatures reached $28{ }^{\circ} \mathrm{C}$ at midday. Tomato seed, cv. BHN 586, were planted in 15-cm-diameter plastic pots in a commercial potting mix (Fafard Soil Mix No. 2). After emergence, plants were fertilized once per week with a 20-20-20 oluble fertilizer $\left(1 \mathrm{~g} \cdot \mathrm{L}^{-1}\right)$ (Agriliance, Inc.)

The experiment was a nested design with three plants nested within each treatment and treatments assigned randomly within each of four blocks. Treatments are presented in Table 1. Applications of bacterial suspensions were made by misting both adaxial and abaxial leaf foces to runoff using a plastic spray bottle. Plants were covered in plastic bags for $3 \mathrm{~d}$ after inoculation. Disease ratings were made $16 \mathrm{~d}$ after inoculation and consisted of the percentbined with that lost from premature defoliation (Pernezny et al., 1996). The experiment was repeated. Disease severity ratings were subjected to analyses of variance, and treatment means were compared using Waller and Duncan's method at $P \leq 0.05$ in SAS (Version 9.1; SAS Institute, Inc., Cary, NC).

Field trials at SWFREC. For trials conducted at the SWFREC in Spring 2007, Fall 2007, and Fall 2008, 4- to 6-week-old transplants were obtained from Barnett Transplant Co., Felda, FL. Trials at SWFREC were conducted on-site in a field with soil type Immokalee fine sand and guidelines established by the University of Florida/IFAS were followed for land preparation, fertility, irrigation, weed (Olson et al. 2007). In Spring 2007, tomato seedlings cv. Hazera 3073 were transplanted on 6 Mar. into plete block design with four replications. Each plot consisted of 15 plants spaced $46 \mathrm{~cm}$ apart with $3 \mathrm{~m}$ between each plot. Beds were $0.8 \mathrm{~m}$ wide on 1.8-m centers and covered with black polyethylene film. Nine spray applications were made at 7-d intervals on 20 and 27 Mar.; 3, 10, 17, and 24 Apr.; and 1, 8, and 15 May. All test materials were applied with a high-clearance sprayer designed specifically for applications in staked tomato plots at a tractor speed of $3.2 \mathrm{~km} \cdot \mathrm{hr}^{-1}$ and a pressure of $1400 \mathrm{KPa}$. A double-drop boom equipped with six nozzles delivered a spray volume of $615 \mathrm{~L} \cdot \mathrm{ha}^{-1}$. age of leaf surface covered with lesions com- 
Treatments are presented in Table 2. Plots were inoculated with bacterial suspension on 12 and 27 Apr. A visual assessment was made of the percentage of foliage covered with lesions plus that lost as a result of premature defoliation combined into one rating (Pernezny et al., 1996) on 26 Apr. and 21 May. All fruit were harvested once on 23 May and the number and weight of marketable and non-marketable (small, misshapen, or diseased) fruit were recorded.

The experimental design for the trial conducted in Fall 2007 was essentially the same as the spring except that tomato cv. FL 47 was planted on 4 Sept. In this trial, treatments evaluated kasugamycin in a program in combination with copper hydroxide and mancozeb or in rotation with these products. Plants were inoculated with bacteria once on 4 Oct. using the same methodology. In this trial, sprays were initiated on 11 Sept. and continued at weekly intervals for 14 sprays. Disease severity ratings (percentage symptomatic tissue) were estimated for bacterial spot on 18 Oct. and 2 Nov. Fruit was harvested on 5 and 6 Dec. Fruit were categorized as either marketable or nonmarketable (small, misshapen, or diseased) and counted and weighed.
The Fall 2008 trial repeated the treatments from Spring 2007 with the same experimental design. Tomato plants cv. FL 47 were transplanted on 24 Sept. Nine sprays were applied beginning the week after transplanting on 30 Sept. Plants were inoculated with the bacterial suspension prepared as previously described on 17 and 31 Oct. and 13 Nov. Disease severity ratings (percentage symptomatic tissue) were estimated for bacterial spot on 18 Oct. and 10 and 21 Nov.

Area under disease progress curve (AUDPC) was calculated from disease data using the trapezoidal method with midpercentage values (Jeger, 2004) and was subject to one-way analysis of variance (ANOVA) and subjected to GLM. Significant differences between means were separated using Fisher's protected least significant difference using SAS 9.1 (Statistical Analysis System; SAS Institute, Inc.). Disease severity ratings and yield data were subjected to ANOVA followed by mean separation using Waller and Duncan's method at $P \leq 0.05$.

Field trial at GCREC. Field plots were established on 4 Sept. 2008 at GCREC, Balm, FL. Seedlings of the Tomato yellow leaf curl virus-resistant cv. SecuriTY 28 were trans- planted at $45-\mathrm{cm}$ spacing to $6.4-\mathrm{m}$ plots along 91.5-m-long, raised beds with 1.5 -m centerto-center bed spacing. Beds were covered with a silver, virtually impermeable film mulch and irrigated with a drip system using guidelines established by the University of Florida/IFAS for land preparation, fertility, irrigation, weed management, and insect control (Olson et al., 2007). Treatments are presented in Table 3.

Plants were treated weekly, beginning 28 Aug., as seedlings in the greenhouse and continuing after transfer to the field. $\mathrm{A} \mathrm{CO}_{2}$ backpack sprayer was calibrated to deliver $559 \mathrm{~L} \cdot \mathrm{ha}^{-1}$ for the first seven applications and $839 \mathrm{~L} \cdot \mathrm{ha}^{-1}$ for the subsequent applications at $280 \mathrm{KPa}$. Treatments were arranged in a randomized complete block design with each treatment replicated four times. Plots were inoculated with a bacterial suspension on 17 Sept. and 30 Sept. Plots were monitored and rated using the Horsfall-Barratt scale (Horsfall and Barratt, 1945) to assess the percentage of canopy affected by bacterial leaf spot. Disease ratings on 9 Oct. and 15 Oct. assessed the entire plant canopy, whereas later ratings on 27 Oct. and 13 Nov. only assessed the top half of the canopy because of excessive foliar blighting of the lower canopy.

Table 2. Suppression of bacterial spot on tomato by kasugamycin, copper hydroxide, and mancozeb alone or in combination in field trials conducted at Southwest Florida Research and Education Center, Immokalee, FL, in Spring 2007 and Fall 2007 and 2008.

\begin{tabular}{|c|c|c|c|c|c|c|c|c|c|}
\hline \multirow{2}{*}{ Treatment $^{\mathrm{z}}$} & \multirow{2}{*}{ Rate a.i. (ha) ${ }^{\mathrm{x}}$} & \multirow{2}{*}{\multicolumn{2}{|c|}{$\begin{array}{c}\text { Spring } 2007 \\
\text { Disease severity }^{\mathrm{y}}\end{array}$}} & \multirow{2}{*}{\multicolumn{2}{|c|}{$\begin{array}{c}\text { Fall } 2007 \\
\text { Disease severity }\end{array}$}} & \multirow{2}{*}{\multicolumn{3}{|c|}{$\begin{array}{c}\text { Fall } 2008 \\
\text { Disease severity }\end{array}$}} & \multirow{2}{*}{$\mathrm{AUDPC}^{\mathrm{w}}$} \\
\hline & & & & & & & & & \\
\hline Control & & $23.8 \mathrm{a}^{\mathrm{v}}$ & 40.5 & $19.5 \mathrm{a}$ & 21.3 & 8.8 & 10.0 & 15.0 & 358 \\
\hline Kasugamycin $(1-9,1-14)$ & $5 \mathrm{~mL} \cdot \mathrm{L}^{-1}$ & $10.5 \mathrm{~b}$ & 42.0 & - & - & 2.5 & 8.1 & 8.3 & 205 \\
\hline Kasugamycin + copper hydroxide $(1-9,1-14)$ & $5 \mathrm{~mL} \cdot \mathrm{L}^{-1}+1.3 \mathrm{~kg}$ & $16.0 \mathrm{ab}$ & 33.2 & - & - & 1.3 & 8.9 & 5.8 & 202 \\
\hline Kasugamycin + captan $(1-14)$ & $5 \mathrm{~mL} \cdot \mathrm{L}^{-1}+9.0 \mathrm{~g} \cdot \mathrm{L}^{-1}$ & $10.3 \mathrm{~b}$ & 35.2 & - & - & 2.0 & 6.6 & 8.8 & 188 \\
\hline $\begin{array}{l}\text { Kasugamycin + copper hydroxide, }(1,3,5,7,9) \\
\text { alt. copper hydroxide + mancozeb }(2,4,6,8)\end{array}$ & $\begin{array}{l}5 \mathrm{~mL} \cdot \mathrm{L}^{-1}+0.325 \mathrm{~kg} \\
\text { alt. } 1.3+1.68 \mathrm{~kg}\end{array}$ & - & - & - & - & 5.0 & 4.8 & 8.3 & 190 \\
\hline Kasuran $^{\circledR} 50 \mathrm{WP}$ & $0.975 \mathrm{~kg} / \mathrm{a} . \mathrm{i}$ & $17.3 \mathrm{ab}$ & 40.0 & - & - & - & - & - & - \\
\hline $\begin{array}{l}\text { Kasugamycin }(1,2,4,5,7,9) \text { alt. mancozeb }+ \\
\quad \text { copper hydroxide }(3,6,8,9,10,11,12,13,14)\end{array}$ & $\begin{array}{l}5 \mathrm{~mL} \cdot \mathrm{L}^{-1} \text { alt. } \\
1.68 \mathrm{~kg}+1.0 \mathrm{~kg}\end{array}$ & - & - & $12.0 \mathrm{ab}$ & 16.3 & - & - & - & - \\
\hline $\begin{array}{l}\text { Kasugamycin }(1,2,4,5,7,9) ; \text { mancozeb }+ \\
\quad \text { copper hydroxide }(1-14)\end{array}$ & $\begin{array}{l}5 \mathrm{~mL} \cdot \mathrm{L}^{-1}+1.68 \mathrm{~kg} \\
\quad+1.0 \mathrm{~kg}\end{array}$ & - & - & $10.3 \mathrm{~b}$ & 13.8 & - & - & - & - \\
\hline$P>\mathrm{F}$ & & 0.05 & 0.62 & 0.006 & 0.0933 & 0.32 & 0.77 & 0.067 & 0.41 \\
\hline
\end{tabular}

${ }^{2}$ Numbers in parentheses represent application times at weeks after transplanting. Nine sprays were applied for season beginning $7 \mathrm{~d}$ after transplanting in Spring 2007 and Fall 2008 and 14 sprays were applied in same pattern in Fall 2007.

${ }^{y}$ Estimate of percentage of plant tissue exhibiting symptoms of bacterial spot.

${ }^{x}$ Rate in hectare except where indicated in a.i. per liter.

wArea under disease progress curve (AUDPC) was calculated using the trapezoidal method with the midpercentage values from the Fall 2008 trial.

vDifferences in means followed by the same letter are not significant at $P \leq 0.05$ or $P$ value indicated.

Table 3. Marketable and non-marketable fruit from trial conducted at Southwest Florida Research and Education Center, Immokalee, FL, in Fall 2007.

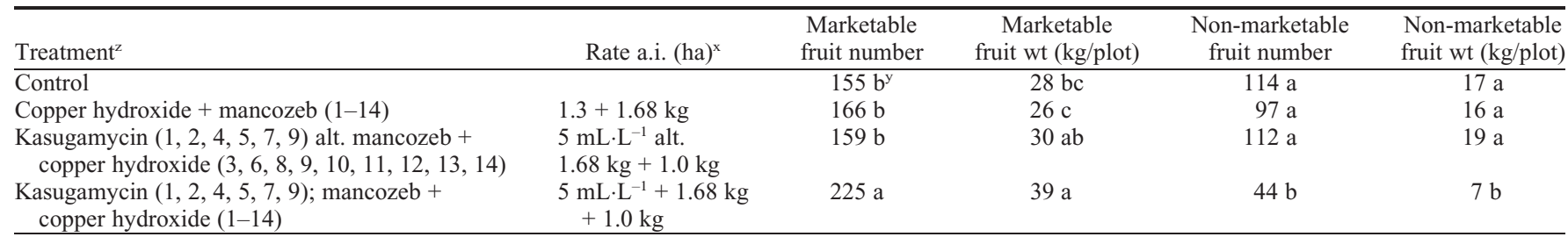

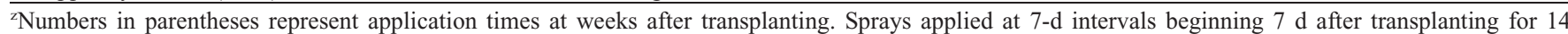
applications.

${ }^{x}$ Rate in hectare except where indicated in a.i. per liter.

${ }^{\mathrm{y}}$ Differences in means followed by the same letter are not significant at $P$ value $\leq 0.05$. 
Table 4. Suppression of bacterial spot on tomato by kasugamycin, copper hydroxide, and mancozeb alone or in combination in field trials conducted at Gulf Coast Research and Education Center, Balm, FL, in Fall 2008.

\begin{tabular}{|c|c|c|c|c|c|c|}
\hline \multirow[b]{2}{*}{ Treatment $^{\mathrm{z}}$} & \multirow[b]{2}{*}{ Rate a.i. (ha) ${ }^{\mathrm{x}}$} & \multicolumn{4}{|c|}{ Disease severity ${ }^{y}$} & \multirow[b]{2}{*}{ AUDPC $^{w}$} \\
\hline & & 9 Oct. & 15 Oct. & 27 Oct. & 13 Nov. & \\
\hline Control & & $13.8 \mathrm{~b}^{\mathrm{v}}$ & 25.6 & 0.8 & $32.8 \mathrm{~b}$ & $761 \mathrm{bc}$ \\
\hline Copper sulfate $(2-13)+$ mancozeb $(3-13)$ & $0.68 \mathrm{~kg}+1.68 \mathrm{~kg}$ & $13.8 \mathrm{~b}$ & 23.3 & 0.8 & $43.8 \mathrm{~b}$ & $832 \mathrm{c}$ \\
\hline$P>\mathrm{F}$ & & 0.0230 & 0.5385 & 0.4363 & 0.0022 & 0.0052 \\
\hline
\end{tabular}

Table 5. Suppression of bacterial spot on tomato by kasugamycin, copper hydroxide, and mancozeb alone or in combination in field trials conducted at Plant Science Unit, Citra, FL.

\begin{tabular}{|c|c|c|c|c|c|c|c|c|c|c|}
\hline \multirow{2}{*}{ Treatment $^{2}$} & \multirow{2}{*}{$\begin{array}{l}\text { Rate a.i. }{ }^{x} \\
\text { (ha) }\end{array}$} & \multicolumn{4}{|c|}{ Spring 2007} & \multicolumn{5}{|c|}{ Fall 2007} \\
\hline & & \multicolumn{4}{|c|}{ Disease severity ${ }^{\mathrm{y}}$} & \multicolumn{5}{|c|}{ Disease severity } \\
\hline Control & & $7.0 \mathrm{a}^{\mathrm{v}}$ & 30.1 & 46.7 & 891 & $7.2 \mathrm{a}$ & $13.5 \mathrm{a}$ & 31.6 & $27.5 \mathrm{ab}$ & 814 \\
\hline Copper hydroxide + mancozeb (1-9) & $\begin{array}{l}0.45 \mathrm{~kg} \\
+0.64 \mathrm{~kg}\end{array}$ & $4.4 \mathrm{~b}$ & 20.6 & 34.7 & 622 & $4.8 \mathrm{~b}$ & $11.6 \mathrm{ab}$ & 32.9 & $35.3 \mathrm{a}$ & 843 \\
\hline Kasugamycin $(1,3,5,7,9)$ & $100 \mathrm{ppm}$ & $4.8 \mathrm{~b}$ & 21.8 & 39.0 & 677 & $6.3 \mathrm{ab}$ & $10.0 \mathrm{~b}$ & 27.7 & $26.0 \mathrm{~b}$ & 707 \\
\hline $\begin{array}{l}\text { Kasugamycin + copper hydroxide } \\
\quad+\text { mancozeb }(1-9)\end{array}$ & $\begin{array}{l}100 \mathrm{ppm} \\
+0.45 \mathrm{~kg} \\
+0.64 \mathrm{~kg}\end{array}$ & $4.4 \mathrm{~b}$ & 17.7 & 36.7 & 595 & $5.0 \mathrm{~b}$ & $9.6 \mathrm{~b}$ & 42.4 & $38.7 \mathrm{a}$ & 970 \\
\hline$P>\mathrm{F}$ & & 0.0129 & 0.0786 & 0.1848 & 0.0620 & 0.0285 & 0.0122 & 0.0812 & 0.0198 & 0.0986 \\
\hline
\end{tabular}

AUDPC was calculated from disease data as described previously. Marketable yield was assessed from two separate harvests of the center 10 plants in each plot. Only extralarge and ripe fruit were harvested on 14 Nov. followed by a complete harvest of all fruit on 2 Dec. Yield and disease severity data were statistically analyzed using the MIXED procedure in SAS Version 9.2 (Statistical Analysis System SAS Institute, Inc.). Differences among least square means were tested using Tukey's adjustment.

Field trials at PSREU. Field plots were established on 1 May and 21 Aug. 2007 for a respective late spring and fall bacterial spot trial at the University of Florida's PSREU in Citra, FL. For both trials, tomato seedlings of the $\mathrm{cv}$. Bella Rosa were transplanted at $46-\mathrm{cm}$ spacing to raised, fumigated beds with $1.8-\mathrm{m}$ center-to-center bed spacing. Beds were covered with a silver, virtually impermeable film mulch and irrigated with a drip system using guidelines established by the University of Florida/IFAS for land preparation, fertility, irrigation, weed management, and insect control (Olson et al., 2007). Treatments are pre- sented in Table 4. Twelve-plant treatment plots were arranged in a randomized complete block design with each treatment replicated four times. Plants were treated weekly, beginning after transplanting and continuing throughout the season, using a $\mathrm{CO}_{2}$ backpack sprayer calibrated to $559 \mathrm{~L} \cdot \mathrm{ha}^{-1}$ or $839 \mathrm{~L} \cdot \mathrm{ha}^{-1}$ at 275 $\mathrm{KPa}$. Inoculum of $X$. perforans race T4 was prepared as described previously and used to inoculate the fifth plant of each plot with a $10^{8} \mathrm{cfu} / \mathrm{mL}$ bacterial suspension on 9 May and 21 Sept. for spring and fall trials, respectively. Plots were monitored and rated using the Horsfall-Barratt scale as described previously. Marketable yield was assessed from a single harvest of each plot. Yield and disease severity data were statistically analyzed using the MIXED procedure in SAS Version 9.2 (Statistical Analysis System SAS Institute, Inc.) and to test for differences among least square means.

Recovery of kasugamyacin-resistant strains. Diseased leaf tissues were sampled from three of four replicated plots from field trials at SWFREC for the following treatments: control, kasugamycin, and kasugamycin + copper hydroxide on 26 Apr. and 21 May for the Spring 2007 trial and once on 4 Dec. in the Fall 2008 trial. Xanthomonas strains were isolated to determine their sensitivity to kasugamycin in vitro. Briefly, a flamed and cooled inoculation needle with a small right-angle bend at the tip was inserted through the margin of diseased tissue and, without removal, streaked onto duplicate plates of nutrient agar supplemented with $50 \mu \mathrm{g} \cdot \mathrm{mL}^{-1}$ of cycloheximide. Plates were incubated at $28{ }^{\circ} \mathrm{C}$ for $3 \mathrm{~d}$. Single yellow colonies characteristic of Xanthomonas were isolated from the initial plates onto nutrient agar containing $0.5 \%$ glucose (GNA). Cultures were restreaked as necessary to ensure purity and stored in sterile $15 \%$ aqueous glycerol at $-70{ }^{\circ} \mathrm{C}$.

In Spring 2007, a total of nine strains was isolated on each sampling date. These strains were streaked on two GNA plates containing $100 \mu \mathrm{g} \cdot \mathrm{mL}^{-1}$ kasugamycin (Sigma Chemical, St. Louis, MO) and two control plates without kasugamycin amendment. After 3 dincubation at $28{ }^{\circ} \mathrm{C}$, growth on GNA with and without kasugamycin was qualitatively compared as a measure of strain sensitivity to kasugamycin. 
In Fall 2008, a slightly different procedure was used in that the growth of strains was compared on GNA plates (controls) and plates amended with $5.0 \mathrm{~mL} \cdot \mathrm{L}^{-1}$ of Kasumin ${ }^{\circledR} 2 \mathrm{~L}$, which corresponded to $109 \mu \mathrm{g} \cdot \mathrm{mL}^{-1}$ a.i. of kasugamycin, was added after the medium was autoclaved and cooled to $55^{\circ} \mathrm{C}$. Estimates of the percentage growth of strains collected from all treatments were made in triplicate on the kasugamycin-amended compared with control plates after $4 \mathrm{~d}$ incubation at $28^{\circ} \mathrm{C}$.

\section{Results}

Greenhouse experiment. Tomato plants treated with kasugamycin, with the exception of Kasuran ${ }^{\circledR}$ (kasugamycin + copper hydroxide pre-mix) formulation, exhibited reduced bacterial spot severity (Table 1). Although not striking, differences between the control and the kasugamycin treatments were often statistically significant, representing as high as a $37.5 \%$ reduction in disease severity for some treatments. No statistical effect was observed with the addition of copper or captan to kasugamycin versus kasugamcyin alone (Table 1).

Field trials: Spring 2007, SWFREC. In the first rating, disease severity was significantly less on plants treated with kasugamycin compared with the control plants (Table 2). For example, plants receiving kasugamycin alone received a disease rating of $10.5 \%$ compared with $23.8 \%$ in the control plots, less than half as much foliar damage. There was no statistical advantage to applying kasugamycin as a mixture with copper hydroxide or captan for disease control. At $\approx 1$ month later, no significant differences in disease severity were found among any of the treatments. No differences were found in any of the yield data collected (data not shown), including total number and weight of all fruit harvested, number and weight of marketable and unmarketable fruit, and non-marketable fruit as a percentage of the total weight harvested.

Fall 2007, SWFREC. Although disease severity was suppressed by the copper and mancozeb combination and the addition of kasugamycin, there was no benefit from combining or alternating the two products (Table 2). Yield was significantly higher from plants treated with kasugamycin plus copper alternated with copper plus mancozeb with non-marketable fruit weight significantly reduced; however, this is the only trial in which any differences were detected (Table 3).

Fall 2008, SWFREC. Marginal differences in disease severity were observed among treatments, but only at the final rating at the $P=0.067$ level of significance. Relative to the untreated control, all spray treatments reduced disease severity (Table 2). Although the copper hydroxide and mancozeb and the other treatments reduced the AUDPC by generally more than $40 \%$, no significant differences were detected probably as a result of the variability between plots. No yield data were collected.

Field trial at GCREC. Bacterial spot severity in individual plots ranged from $4.5 \%$ to $18.5 \%$ on 9 Oct. and from $9.0 \%$ to $37.5 \%$ on 15 Oct. with significant differences among treatment means for the first date only $(P=$ 0.0230 and $P=0.5385$, respectively) (Table 4 ). As a result of extreme blighting of the lower canopy, bacterial spot severity was only assessed for the top half of the tomato canopy on 27 Oct. and 13 Nov. and ranged in individual plots from $0 \%$ to $1.5 \%$ and $1.5 \%$ to $62.5 \%$, respectively. Significant differences were detected among treatments on $13 \operatorname{Nov}$. $(P=$ 0.0022 ) with plots treated with kasugamycin alternated with copper sulfate + mancozeb exhibiting a $40 \%$ or better reduction in disease severity relative to the non-treated control and plots treated with copper sulfate + mancozeb. Overall, the spray program that included kasugamycin exhibited significantly less disease over the entire trial as expressed by the AUDPC relative to the copper-mancozeb standard. No significant treatment effect was observed on any yield parameter (data not shown).

Field trials at PSREU. In the spring trial conducted at PSREU, all treatments significantly reduced the severity of bacterial spot compared with the untreated control on 5 June (Table 5). By 19 June, only the combined application of kasugamycin with a half-rate of copper hydroxide + mancozeb was statistically different, and by 3 July, none of the treatments differed significantly from the untreated control although all were numerically less. Based on AUDPC, copper hydroxide + mancozeb treatments with kasugamycin were statistically equivalent to those without and to kasugamycin alone at suppressing bacterial spot at $P=0.0620$.

Results in the fall trial were similar to those of the spring trial initially with most treatments exhibiting reduced bacterial spot severity relative to the untreated control (Table 5). However, by 22 Oct., these differences were no longer evident. The mixed applications of kasugamycin with copper hydroxide + mancozeb appeared to exacerbate disease. On 5 Nov., all treatments were statistically equivalent to the untreated control. None of the treatments differed significantly from the untreated control based on the AUDPC.

Recovery of kasugamycin-resistant strains. In 2007, none of the nine Xanthomonas strains isolated on 26 Apr. in Immokalee showed any signs of kasugamycin resistance (Table 6). However, at least one strain isolated on 21 May from the kasugamycin plots was highly resistant and several others showed some growth on kasugamycin-amended plates. Substantial growth was recorded on kasugamycin-amended plates for strains recovered in Fall 2008 from kasugamycin, kasugamycin/ copper hydroxide, and kasugamycin/captan treatment plots (Table 7). Average growth was least for strains recovered from control plots where no chemical bactericides were applied and greatest for strains recovered from plots where only copper hydroxide was applied.

\section{Discussion}

Kasugamycin provided a level of bacterial spot control on tomato in $\approx 50 \%$ of the greenhouse and field trials. In these instances, control was about the same as that observed with the industry standard of a copper-based salt mixed with mancozeb. In other trials, neither kasugamycin nor the grower standard significantly reduced disease levels. Jones and Jones (1985) also found that available chemical control measures were relatively ineffective when bacterial spot epidemics were severe. If registered for use on tomato in the United States, kasugamycin would give growers an alternative to copper-based bactericides for the management of bacterial spot, especially in areas where copper-tolerant Xanthomonas strains are problematic, and could possibly be alternated with copper + mancozeb as part of an integrated program to manage bacterial spot.

The addition of copper as a formulated additive or a tank-mix option with kasugamycin in general did not improve the level of disease control. Similarly, captan had no synergistic effect when tank-mixed with kasugamycin. Most of the disease control observed in treatments containing kasugamycin was apparently from the kasugamycin itself. Therefore, kasugamycin alone and not in a tank mix would be best in a rotational spray program.

Development of resistance is a major concern any time antibiotics are used routinely. After multiple applications of kasugamycin were made to tomato plants in plots at SWFREC, by the end of the experiment, at least one strain of the bacterial spot pathogen was found to be highly resistant to kasugamycin by an in vitro screening test. Limited growth on kasugamycin-amended plates was observed with several other strains. The fairly rapid development of resistance paralleled that experienced with streptomycin in the past. Rapid development of resistance to streptomycin rendered this once promising chemical ineffective within a few seasons on several vegetable crops (Stall and Thayer, 1962). Based on our experience with streptomycin, this resistance is translated into a marked reduction in product efficacy because natural selection leads to an increased proportion of resistant bacterial strains in the pathogen population. The conventional wisdom is that without continued selection pressure, antibiotic-resistant strains will revert to sensitive wild-type phenotypes (Baquero et al., 1998). However, resistance to streptomycin in populations of Pseudomonas cichorii was long-lived even after streptomycin use was discontinued (Pohronezny et al., 1994). Somewhat surprisingly, plots treated only with copper hydroxide also yielded Xanthomonas strains with kasugamycin resistance. Whether this was the result of movement of strains from plots treated with kasugamycin or selection of insensitive cells in 
Table 6. Resistance to kasugamycin of Xanthomonas perforans or X. euvesicatoria strains on two sampling dates, Southwest Florida Research and Education Center, Immokalee, Spring 2007. ${ }^{2}$

\begin{tabular}{lccc}
\hline & & \multicolumn{2}{c}{ Resistance estimate $^{\mathrm{y}}$} \\
\cline { 2 - 4 } Treatment & Rep & 26 Apr. & 21 May \\
\hline Untreated (control) & 1 & - & + \\
& 2 & - & - \\
Kasugamycin & 3 & - & + \\
& 1 & - & ++ \\
Kasugamycin + copper hydroxide & 2 & - & + \\
& 3 & & - \\
\end{tabular}

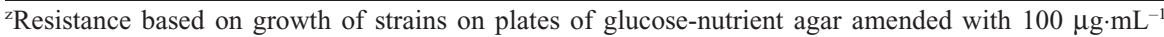
kasugamycin compared with growth on nutrient agar containing $0.5 \%$ glucose plates without kasugamycin.

${ }^{y}$ Qualitative estimate of growth of bacteria on kasugamycin-amended plates where - equals no growth, + equals slight growth, and +++ equals very heavy growth of streaked cultures. Plates were streaked in duplicate.

Table 7. Resistance to kasugamycin of Xanthomonas perforans or $X$. euvesicatoria strains recovered from plots treated seasonlong with kasugamycin, Southwest Florida Research and Education Center, Immokalee, Fall 2008. ${ }^{\mathrm{z}}$

\begin{tabular}{lc}
\hline Treatment & $\begin{array}{c}\text { Percent growth } \\
\text { on plates } \\
\text { containing } \\
\text { kasugamycin }\end{array}$ \\
\hline Control & $10 \mathrm{a}$ \\
Copper hydroxide & $67 \mathrm{~b}$ \\
Kasugamycin & $27 \mathrm{a}$ \\
Kasugamycin + copper hydroxide & $29 \mathrm{a}$ \\
Kasugamycin + captan & $40 \mathrm{ab}$ \\
\hline
\end{tabular}

${ }^{\mathrm{z}}$ Based on assessment of growth on glucosenutrient agar plates amended with $109 \mu \mathrm{g} \cdot \mathrm{mL}^{-1}$ kasugamycin compared with unamended control plates.

${ }^{\mathrm{y}}$ Numbers are means of three replications. Differences in means followed by the same letter are not significant at $P \leq 0.05$.

the population on the amended media was not examined. The resistance to kasugamycin among strains collected from plots sprayed only with copper could reflect a physiological linkage between resistance to both substances. If this is the case, the widespread distribution of copper resistance among $X$. perforans and related strains in Florida will limit the potential use of kasugamycin for bacterial disease control. We recommend that kasugamycin be alternated with other materials and, ideally, the number of applications per season should be limited. However, as more options for the control of bacterial spot are becoming available such as bacteriophage, plant defense activators, phosphorous acid, and Tanos ${ }^{\circledR}$ (Balogh et al., 2003; Byrne et al., 2005; Roberts et al., 2008), the addition of this antibiotic increases the options available to growers for managing this disease.

\section{Literature Cited}

Balogh, B., J.B. Jones, M.T. Momol, S.M. Olson, A. Obradovic, P. King, and L.E. Jackson. 2003.
Improved efficacy of newly formulated bacteriophages for management of bacterial spot on tomato. Plant Dis. 87:949-954.

Baquero, F., M.-C. Negri, M.-I. Morosini, and J. Blazquez. 1998. Antibiotic-selective environments. Clin. Infect. Dis. 27:S5-S11.

Byrne, J.M., A.C. Dianese, P. Ji, H.L. Campbell, D.A. Cuppels, F.J. Louws, S.A. Miller, J.B Jones, and M. Wilson. 2005. Biological control of bacterial spot of tomato under field conditions at several locations in North America. Biol. Control 32:408-418.

EPA. 2005. Kasugamycin; pesticide tolerance. U.S. Environmental Protection Agency, Office of Prevention, Pesticides and Toxic Substances. Fed. Regist. 70:55748-55752.

Flaherty, J.E., J.B. Jones, B.K. Harbaugh, G.C. Somodi, and L.E. Jackson. 2000. Control of bacterial spot on tomato in the greenhouse and field with h-mutant bacteriophages. HortScience $35: 882-884$

Fravel, D. 2005. Commercialization and implementation of biocontrol. Annu. Rev. Phytopathol. 43:337-359.

Gent, D.H. and H.F. Schwartz. 2005. Management of Xanthomonas leaf blight of onion with a plant activator, biological control agents, and copper bactericides. Plant Dis. 89:631-639.

Graves, A.S., and S.A. Alexander. 2002. Managing bacterial speck and spot of tomato with acibenzolar-S-methyl in Virginia. Plant Health Progress. doi:1094/PHP-2002-0220$01-\mathrm{RS}$.

Horsfall, J.G. and R.W. Barratt. 1945. An improved grading system for measuring plant diseases. Phytopathology 35:655.

Jeger, M.J. 2004. Analysis of disease progress as a basis for evaluating disease management practices. Annu. Rev. Phytopathol. 42: 61-82.

Ji, P., H.L. Campbell, J.W. Kloepper, J.B. Jones, T.V. Suslow, and M. Wilson. 2006. Integrated biological control of bacterial speck and spot of tomato under field conditions using foliar biological control agents and plant growth-promoting rhizobacterial. Biol. Control 36:358367.

Jones, J.B. 1991. Bacterial spot, p. 27. In: Jones, J.B., J.P. Jones, R.E. Stall and T.A. Zitter (eds.) Compendium of tomato diseases. APS Press, St. Paul, MN.

Jones, J.B. and J.P. Jones. 1985. The effect of bactericides, tank mixing time and spray sched- ule on bacterial leaf spot of tomato. Proc. Fla. State Hort. Soc. 98:244-247.

Jones, J.B., G.H. Lacy, H. Bouzar, R.E. Stall, and N.W. Schaad. 2004. Reclassification of the xanthomonads associated with bacterial spot disease of tomato and pepper. Syst. Appl. Microbiol. 27:755-762.

Jones, J.B., R.E. Stall, and H. Bouzar. 1998. Diversity among xanthomonads pathogenic on pepper and tomato. Annu. Rev. Phytopathol 36:41-58.

Leben, C., G.C. Daft, and A.F. Schmitthenner. 1968. Bacterial blight of soybeans: Population levels of Pseudomonas glycinea in relation to symptom development. Phytopathology 58 $1143-1146$

Louws, F.J., M. Wilson, H.L. Campbell, D.A. Cuppels, J.B. Jones, P.B. Shoemaker, F. Sahin, and S.A. Miller. 2001. Field control of bacterial spot and bacterial speck of tomato using a plant activator. Plant Dis. 85:481-488.

Marco, G.M. and R.E. Stall. 1983. Control of bacterial spot of pepper initiated by strains of Xanthomonas campestris pv. vesicatoria that differ in sensitivity to copper. Plant Dis. 67: 779-781.

Minsavage, G.V., B.I. Canteros, and R.E. Stall. 1990. Plasmid-mediated resistance to streptomycin in Xanthomonas campestris pv. vesicatoria. Phytopathology 80:719-723.

Obradovic, A., J.B. Jones, M.T. Momol, B. Balogh, and S.M. Olson. 2004. Management of tomato bacterial spot in the field by foliar applications of bacteriophages and SAR inducers. Plant Dis. 88:736-740.

Olson, S.M., W.M. Stall, T.M. Momol, S.E. Webb, T.G. Taylor, S.A. Smith, and E.H. Simonne. 2007. Tomato production in Florida, p. 409429. In: Olson, S.M. and E. Simmone (eds.). Vegetable production guide for Florida, 20072008. University of Florida, Institute of Food and Agricultural Science Extension Service, Gainesville, FL.

Pernezny, K., L.E. Datnoff, T. Mueller, and J. Collins. 1996. Losses in fresh-market tomato production in Florida due to target spot and bacterial spot and the benefits of protectant fungicides. Plant Dis. 80:559-563.

Pohronezny, K., M.L. Sommerfeld, and R.N. Raid. 1994. Streptomycin resistance and copper tolerance among strains of Pseudomonas cichorii in celery seedbeds. Plant Dis. 78:150 153.

Pohronezny, K., R.E. Stall, B.I. Canteros, M. Kegley, L.E. Datnoff, and R. Subramanya. 1992. Sudden shift in the prevalent race of Xanthomonas campestris pv. vesicatoria in pepper fields in southern Florida. Plant Dis. 76:118-120.

Pohronezny, K. and R.B. Volin. 1983. The effect of bacterial spot on yield and quality of fresh market tomatoes. HortScience 18:69-70.

Ritchie, D.F. and U. Dittapongpitch. 1991. Copperand streptomycin-resistant strains and hostdifferentiated races of Xanthomonas campestris pv. vesicatoria in North Carolina. Plant Dis. 75:733-736.

Roberts, P.D., M.T. Momol, L. Ritchie, S.M. Olson, J.B. Jones, and B. Balogh. 2008. Evaluation of spray programs containing famoxadone plus cymoxanil, acibenzolar-S-methyl, and Bacillus subtilis compared to copper sprays for management of bacterial spot on tomato. Crop Prot. 27:1519-1526.

Romero, A.M., C.S. Kousik, and D.F. Ritchie. 2001. Resistance to bacterial spot in bell pepper induced by acidbenzolar-S-methyl. Plant Dis. 85:189-194. 
Scott, J.W., G. Cameron Somodi, and J.B. Jones. 1989. Resistance to bacterial spot fruit infection in tomato. HortScience 24:825-827.

Scott, J.W. and J.B. Jones. 1986. Sources of resistance to bacterial spot in tomato. HortScience 21:304-306.

Scott, J.W., S.A. Miller, R.E. Stall, J.B. Jones, G.C. Somodi, V. Barbosa, D.L. Francis, and F. Sahin. 1997. Resistance to race T2 of the bacterial spot pathogen in tomato. HortScience 32:724-727.
Stall, R.E. and P.L. Thayer. 1962. Streptomycin resistance of the bacterial spot pathogen and control with streptomycin. Plant Dis. Rep. 46: 389-392.

USDA. 2010. Vegetables: 2009 summary. U.S. Department of Agriculture, National Agricultural Statistics Service. January 2010. Vg 1-2 (10).

VanSickle, J. and R. Weldon. 2009. The economic impact of bacterial leaf spot on the tomato industry. 2009 Proceedings of the Florida Tomato Institute. p. 30-31.

Vauterin, L., B. Hoste, K. Kersters, and J. Swings. 1995. Reclassification of Xanthomonas. Int. J. Syst. Bacteriol. 45:472-489.

Woodcock, J., D. Moazed, M. Cannon, J. Davies, and H.F. Noller. 1991. Interaction of antibiotics with A- and P- site-specific bases in 16S ribosomal RNA. EMBO J. 10:30993103 . 